\title{
OPTIMALISASI PROSES PENGEMBALIAN UANG PENGGANTI DALAM TINDAK PIDANA KORUPSI DI INDONESIA (Studi Kasus di Pengadilan Negeri Poso)
}

\author{
I Ketut Suarbawa \\ Email:ksuarbawa@rocketmail.com \\ Mahasiswa Program Magister Ilmu Hukum Program Pascasarjana \\ Fakultas Hukum Universitas Sebelas Maret Surakarta \\ Hari Purwadi \\ Email: Hpurwadie@gmail.com \\ Dosen Fakultas Hukum Universitas Sebelas Maret Surakarta \\ Supanto \\ Email: supanto07@yahoo.com \\ Dosen Fakultas Hukum Universitas Sebelas Maret Surakarta
}

\begin{abstract}
This article is intended to analyze the factors that are in the process of recovery. The question in this study is what factors contributed to the criminal proceedings at the Poso District Court. This research is Soicio Legal research. This research uses case and concept approach, while data data technique by inventory of case study method and literature study or secondary data only. The results of appropriate research to punish the perpetrators of corruption with imprisonment, which is no less important is the punishment of the perpetrators to restore the state finances due to state losses incurred in the criminal act of corruption. In some cases, state financial refunds can not be effec-tively effected, this is due to several factors, including factors of law, law enforcement factors, facilities and community factors.
\end{abstract}

Keywords: Optimization; Substitute Money; Corruption.

\begin{abstract}
Abstrak
Artikel ini bertujuan untuk menganalisis tentangfaktor-faktor yang mempengaruhi proses pengembalian uang pengganti dalam tindak pidana korupsidi Pengadilan Negeri Poso. Yang menjadi permasalahan dalam penelitian ini adalah apa saja faktor-faktor yang mempengaruhi proses pengembalian uang pengganti dalam tindak pidana korupsidi Pengadilan Negeri Poso. Penelitian ini merupakan penelitian Soicio Legal. Penelitian ini menggunakan pendekatan kasus dan konsep, sedangkan teknik pengumpulan data dilakukan dengan cara inventarisasi cara meneliti studi kasus dan studi pustaka atau data sekunder belaka. Hasil penelitian menunjukan bahwa dilakukannya pemberantasan tindak tidana korupsi seharusnyatidak semata-mata bertujuan untuk menghukum pelaku korupsi dengan pidana penjara, tetapi yang tidak kalah pentingnya adalah penghukuman kepada pelaku untuk pengembalian keuangan negara akibat kerugian negara yang ditimbulkan dalam tindak pidana korupsi. Dalam beberapa kasus, pengembalian keuangan negara tidak dapat dilakukan secara efektiv, hal ini disebabkan oleh beberapa faktor, diantaramya faktor undang-undangnya, faktor penegak hukum, faktor fasilitas dan faktor masyarakat.
\end{abstract}

Kata kunci: Optimalisasi; Uang Pengganti; Korupsi. 


\section{A. Pendahuluan}

Di berbagai belahan dunia, korupsi selalu mendapatkan perhatian yang lebih dibandingkan dengan tindak pidana lainnya. Fenomena ini dapat dimaklumi mengingat dampak negatif yang ditimbulkan oleh tindak pidana ini. Dampak yang disimpulkan dapat menyentuh berbagai bidang kehidupan. Korupsi merupakan masalah serius, tindak pidana ini dapat membahayakan stabilitas dan keamanan masyarakat, membahayakan pembangunan sosial ekonomi, dan juga politik, serta dapat merusak nilai-nilai demokratis dan moralitas karena lambat laun perbuatan ini seakan menjadi sebuah budaya. Korupsi merupakan ancaman terhadap cita menuju masyarakat adil dan makmur.(Evi Hartanti,2007:1)

Tujuan dari dikeluarkannya Undang-undang Tipikor adalah tidak semata-mata bertujuan agar para koruptor dijatuhi hukuman pidana penjara yang dapat menimbulkan efek jera terhadap pelaku korupsi, tetapi harus juga dapat mengembalikan kerugian Negara yang telah ditimbulkan akibat tindak pidana korupsi yang terjadi. Pengembalian kerugian Negara ini menjadi hal yang penting karena memiliki tujuan dan harapan dapat memulihkan/ mengembalikan kemampuan Negara dalam membiayai berbagai pembangunan disegala aspek kehidupan masyarakat yang sangat dibutuhkan ditengah segala keterbatasan Negara khususnya dalam kemampuan keuangan.

Kuatnya tuntutan masyarakat kepada pemerintah untuk serius memerangi korupsi direspon oleh pemerintah melalui berbagai kebijakan. Salah satunya dengan mengeluarkan Undang-Undang Pemberantasan Tindak Pidana Korupsi yang terakhir yaitu Undang-Undang No. 31 Tahun 1999 yang telah diubah dan ditambah dengan Undang-undang No. 20 Tahun 2001 selanjutnya akan disebut dengan UU Tipikor. Alasan pemerintah mengeluarkan UndangUndang No. 31 Tahun 1999 jo. Undang-Undang No. 20 Tahun 2001 karena Undang-Undang Pemberantasan Tindak Pidana Korupsi No. 3 Tahun 1971 (UU Tipikor) dianggap belum mampu menjawab kebutuhan hukum dalam pemberantasan korupsi dan dinilai sangat lemah, khususnya dalam hal pidana dan pemidanaan.

Pada tahun 2012, menurut hasil Survey Transparancy International (TI) Indonesia yang pada tahun 2011 menempati urutan ke- 6 negara terkorupsi dengan angka indeks persepsi korupsi (IPK) adalah 2,4. Sementara di Asia, berdasarkan hasil survai Politicaland Economic Risk Consultacy (PERC), lembaga pemberi peringkat yang berbasis di Hongkong, pada tahun 2013 Indonesia menduduki urutan kedua bersama Thailand sebagai negara terkorup di Asia dengan angka IPK 8,03 setelah Filipina. Penurunan peringkat sebagai negara terkorup di Asia ini dikarenakan adanya Political Will dari pemerintah Indonesia untuk memberantas korupsi.

Tidaklah berlebihan jika Romli Atmasasmita mengatakan korupsi di Indonesia sudah merupakan virus yang telah menyebar keseluruh tubuh pemerintah sejak tahun 1960-an hingga saat ini dan langkah-langkah pemberantasan pun masih tersendat-sendat. Korupsi berkaitan pula dengan kekuasaan karena dengan kekuasaan itu penguasa dapat menyalahgunakan kekuasaan untuk kepentingan pribadi, keluarga atau kroninya. Kemudian ditegaskan bahwa korupsi selalu bermula pada sektor publik dengan bukti-bukti yang nyata bahwa dengan kekuasaan itulah pejabat publik dapat menekankan atau merampas para pencari keadilan atau mereka yamng memerlukan jasa pelayanan dari pemerintah. (Romli Atmasasmita,2004:1)

Beberapa faktor lainnya adalah beberapa penegakan hukum yang tidak konsisten, penyalahgunaan kekuasaan atau wewenang, langkahnya lingkungan yang antikorup, 
rendahnya pendapatan Negara, kemiskinan dan keserakahan, budaya memberi upeti, imbalan dan hadiah, konsekuensi bila ditangkap lebih rendah daripada keuntungan korupsi, budaya permisif/serba membolehkan, tidak mau tahu, serta gagalnya pendidikan agama dan etika, dan lain sebagainya.

The founding father dengan tegas menetapkan tujuan negara Indonesia sebagaimana tercantum dalam alinea IV Pembukaan Undang-Undang dasar Negara Republik Indonesia Tahun 1945 adalah "melindungi segenap bangsa Indonesia dan seluruh tumpah darah Indonesia, memajukan kesejahteraan umum, mencerdaskan kehidupan bangsa, dan ikut melaksanakan ketertiban dunia, yang berdasarkan kemerdekaan, perdamaian abadi, dan keadilan sosial. Pengembalian aset negara hasil dari tindak pidana korupsi masih sangat jauh dari harapan bangsa Indonesia, sehingga upaya pengungkapan harus betul-betul di jadikan sebagai tolok ukur dalam kesuksesan pemberantasan korupsi disamping semakin berkurangnya tindak pidana korupsin yang terjadi. Pengembalian aset negara hanya sebagai angan-angan belaka masih banyak aset negara yang belum terdeteksi oleh aparat penegak hukum, mengingat bahwa pengembalian keuangan negara hasil dari tindak pidana. korupsi dapat memunculkan berbagai perbuatan tindak pidana korupsi, seperti adanya penimbunan kekayaan hasil korupsi di beberapa daerah atau cara lain yang dilakukan pelaku untuk dapat mengaburkan asal usul aset dan masih banyak belum diketahui keberadanya.(Abd Razak Musahib,2015:1)

Ketentuan mengenai Uang Pengganti diatur dalam pasal 18 dalam UU Tipikor :

1. Selain pidana tambahan dimaksud dalam Kitab Undang-undang Hukum Pidana sebagai pidana tambahan adalah :

a. perampasan barang bergerak yang berwujud atau yang tidak berwujud barangbntidak bergerak yang digunakan untuk yang diperoleh dari tindak pidana korupsi, termasuk perusahaan milik terpidana di mana tindak pidana korupsi dilakukan, begitu pun harga dari barang yang menggantikan barang tersebut;

b. pembayaran uang pengganti yang jumlahnya sebanyak-banyaknya dengan harta benda yang diperoleh dari tindak pidana korupsi.

c. penutupan usaha atau sebagian perusahaan untuk waktu paling lama 1 (satu) tahun;

d. pencabutan seluruh atau sebagian hak-hak tertentu atau penghapusan atau sebagian keuntungan tertentu, yang telah atau dapat diberikan oleh Pemerintah kepada terpidana;

2. Jika terpidana tidak membayar uang pengganti sebagaimana dimaksud ayat (1) huruf b paling lama dalam waktu 1 (satu) bulan sesudah putusan pengadilan berkkekuatan hukum tetap, maka harta bendanya dapat disita oleh Jaksa dan dilelang untuk menutupi uang pengganti tersebut.

3. Dalam hal terpidana tidak mempunyai harta benda yang mencukupi untuk membayar uang pengganti sebagaimana dimaksud dalam ayat (1), maka dipidana dengan pidana penjara yang lamanya tidak melebihi ancaman maksimal dari pidana pokoknya sesuai dengan ketentuan dalam Undang-Undang ini dan lamanya pidana tersebut sudah ditentukan dalam putusan pengadilan.

Yang paling penting juga menyangkut kerugian keuangan negara dari seluruh tindak pidana korupsi yang terjadi. Ketua Komisi Pemberantasan Korupsi (KPK) mengungkapkan, kerugian negara akibat korupsi 2012 sampai 2014 mencapai Rp 689,19 miliar. Data KPK 
memperlihatkan, angka itu berasal dari keuangan Negara dengan nilai sekitar Rp 1,9 Triliun. Kerugian negara tersebut sebagian besar terjadi karena proses penunjukan langsung dalam proyek pengadaan barang dan jasa. Kerugian negara jenis ini mencapai Rp 647 miliar atau 94 persen dari total kerugian negara, Sementara sisa kerugian negara diakibatkan oleh praktik penggelembungan harga, yaitu sebesar Rp 41,3 miliar atau enam persen dari total kerugian negara. 17 Lebih lanjut Ketua KPK menyatakan bahwa jumlah kerugian negara tersebut dihitung setelah ada putusan hukum yang tetap. Tercatat ada 50 perkara korupsi keuangan berupa pengadaan barang dan jasa yang telah diusut KPK. Nilai rata-rata kerugian negara 35 persen dari total nilai proyek (anggaran) Rp 1,9 trilliun. upaya penindakan yang dilakukan Komisi Pemberantasan Korupsi sepanjang tahun 2016 menghasilkan pemasukan negara sebesar Rp 497,6 miliar. Jumlah tersebut meningkat dibanding tahun 2015, di mana penerimaan negara bukan pajak (PNBP) dari KPK saat itu sebesar Rp 211,9 miliar. Penyetoran kepada negara dari hasil pendapatan uang pengganti tindak pidana korupsi yang telah ditetapkan pengadilan sebesar Rp 57,09 miliar. Dalam bidang penindakan tahun 2016, KPK telah melakukan penyelidikan terhadap 96 kasus, penyidikan sebanyak 99 kasus, dan penuntutan sebanyak 77 kasus. (Kompas, 2017) Sedangkan data dari ICW kasus korupsi yang ditangani kejaksaan sebanyak 307 Kasus dan nilai kerugian negara 949 M. Dan kasus korupsi yang ditangani kepolisian sebanyak 140 kasus, nilai kerugian negara $337 \mathrm{M}$ dan nilai suap sebesar $1.9 \mathrm{M}$.

Selama ini Indonesia dalam menangani kasus korupsi lebih cenderung mengutamakan pada penghukuman terhadap pelaku tindak pidana korupsi dari pada pengembalian aset negara. Pemberantasan korupsi difokuskan kepada tiga isu pokok, yaitu pencegahan, pemberantasan, dan pengembalian aset hasil korupsi (asset recovery). Theodorus $\mathrm{M}$. Tuanakota merumuskan setidaknya ada 5 konsep atau metode penghitungan kerugian negara, antara lain : 1. Kerugian Keseluruhan keuangan negara (total loss) 2. Ada selisih antara keuangan negara yang menyebar 3. Harga kontrak dengan nilai selisi keuangan Negara 4. Penerimaan yang menjadi hak negara tapi tidak disetorkan ke kas Negara 5. pengeluaran yang tidak sesuai dengan anggaran, digunakan untuk kepentingan pribadi atau pihak-pihak tertentu.

Pengembalian kerugian negara diharapkan mampu menutupi defisit APBN sehingga dapat menutupi ketidak mampuan negara dalam membiayai berbagai aspek kebutuhan berdasarkan Undang-Undang No 11 Tahun 2009 tentang Kesejahteraan Rakyat. Pengembalian aset negara merupakan pendekatan dalam memerangi kejahatan yang kehadirannya dimulai pada dekade 1980-1988, yang kemudian diterapkan pada jenis kejahatan yang lebih luas dengan dimasukkan Organized Crime tahun 2000.

Negara dalam mengembil keuangan akibat tindak pidana korupsi berdasarkan bukti-bukti yang lebih kuat, bahwa aset tersebut diduga berasal dari pelaku tindak pidana korupsi atau digunakan untuk pelaku tindak pidana korupsi di daera-daerah yang sedang berkembang yang pada umumnya banyak disimpan di sentra-sentra finansial, ini merupakan agenda bagi negara indonesia untuk betul-betul merauk semua uang yang ada di daerah-daera sekecil apapun nilainya. Dengan demikian pemberantasan tindak pidana korupsi juga memperhatikan kepentingan rakyat, disamping memberantas tindak pidana korupsi juga harus memperhatikan pengembalian keuangan negara sebagai akibat perbuatan tersebut, karena korupsi selalu menyangkut keuangan negara. 
Penegakan hukum dan pemulihan aset kejahatan merupakan dua sisi mata uang yang tidak dapat dipisahkan dalam pemberantasan tindak pidana khususnya tindak pidana korupsi. Sebagai kejahatan yang didasari kalkulasi atau perhitungan (crime of calculation), maka pengelolaan dan pengamanan hasil kejahatan merupakan kebutuhan mendasar bagi pelaku kejahatan kerah putih. Seseorang akan berani melakukan korupsi jika hasil yang didapat dari korupsi akan lebih tinggi dari resiko hukuman (penalty) yang dihadapi, bahkan tidak sedikit pelaku korupsi yang siap masuk penjara apabila ia memperkirakan bahwa selama menjalani masa hukuman, keluarganya masih akan dapat tetap hidup makmur dari hasil korupsi yang dilakukan. Oleh karena itulah maka pemberantasan korupsi tidak cukup dengan menghukum para pelakunya, namun harus diimbangi dengan upaya untuk memotong aliran hasil kejahatan. Dengan merampas harta benda yang dihasilkan dari kejahatan korupsi, maka diharapkan pelaku akan hilang motivasinya untuk melakukan atau meneruskan perbuatannya, karena tujuan untuk menikmati hasil-hasil kejahatannya akan terhalangi atau menjadi sia-sia. (Basrief Arief, 2014:2)Berdasarkan fakta-fakta yang penulis paparkan diatas maka dalam artikel ini akan dikaji adalah Faktor-faktor apa yang mempengaruhi proses pengembalian uang pengganti dalam tindak pidana korupsi di wilayah hukum Pengadilan Negeri Poso.

\section{B. Metode Penelitian}

Penelitian Socio Legaladalah penelitian yang bukan penelitian huku dengan menggabungkan penelitian sosial terhadap hukum dengan menganalisa gejalanya di Masyrakat.Menurut Peter Mahmud Marzuki penelitain Socio Legal mapun eneilitian hukum mempunyai objek yang sama yaitu hukum. akan tetapi penelitian yang bersifat Socio Legal hanya enempatkan hukum sebagai gejala sosial. Dalm hal demikian hukum hanya dipandang segi luarnyanya saja. Oleh karena itu penelitian Socio Legalini selalu dikaitkan dengan masalah sosial. Penelitian Socio Legal dimaksudkan untuk mengkaji mengenai EfektivItas Proses Pengembalian Uang Pengganti Dalam Tindak Pidana Korupsi Di Indonesia.

Dalam penelitian hukum ini digunakan beberapa pendekatan diantaranya pendekatan perundang-undangan (statute approach), pendekatan Konsep (conceptual approach) dan pendekatan kasus (case approach)

Sebagai penelitian Socio Legal, maka penelitian ini menggunakan sumber data sekunder (bahan hukum sekunder). Bahan hukum sekunder merupakan bahan yang memberikan penjelasan mengenai bahan hukum primer, seperti rancangan undang-undang, hasil-hasil penelitian baik tesis, skripsi maupun jurnal dan artikel yang berkenaan dengan penelitian. Sehubungan dengan ini maka bahan hukum sekunder Terfokuskan pada EfektivItas Proses Pengembalian Uang Pengganti Dalam Tindak Pidana Korupsi.

Teknik analisa yang digunakan dalam penelitian ini adalah analisa yuridis kualitatif, teknik ini merupakan tatacara penelitian yang menghasilkan data deskriptif yaitu Dimaksudkan untuk memberikan data yang seteliti mungkin tentang manusia, keadaan manusia, keadaan atau gejala -gejala lainnya. Maksudnya adalah terutama untuk mempertegas hipotesa-hipotesa, agar dapat membantu di dalammempertega hipotesa-hipotesa, agar dapat membantu didalam memperkuat teori-teori lama atau dalam kerangka menyusun teori-teori baru. 
I Ketut Suarbawa. Optimalisasi Proses Pengembalian Uang Pengganti dalam Tindak Pidana Korupsi di...

\section{Hasil Penelitian Dan Pembahasan}

Dikemukakan oleh Barda Nawawi Arief, bahwa masalah pembangunan dan penegakanhukum merupakan masalah yang tidak pernahhenti-hentinya dibicarakan, baik secara nasionaldan internasional. Masalah ini akan selalu dan selalu patut dibicarakan, sepanjang kita masih mengakui adanya negara hukum dan sepanjang kita masih mempercayai hukum sebagai salah satu sarana untuk mengatur dan menyelesaikan masalah-masalah kehidupan bermasyarakat. Terlebih dalam era reformasi saat ini, masalah "wibawa hukum" dan "pemerintahan yang bersih dan berwibawa" sedang mendapat tantang-an dan sorotan tajam.

Dilihat dari sudut lembaga pendidikanhukum yang berperan membentuk kualitas Sumber Daya Manusia (SDM) di bidang hukum, maka "peningkatan wibawa hukum" lebih patutdiartikan sebagai "peningkatan kualitas Sumber Daya Manusia (SDM) penegakan hukum". Dengan adanya "peningkatan kualitas penegakan hukum" diharapkan ada "peningkatan wibawa hukum". Meningkatnya kualitas penegakan hukum tentunya juga diharapkan dapat menunjang dan meningkatkan "kualitas pemerintahanyang bersih dan berwibawa" serta mening-katkan "kualitas lingkungan hidup/kualitas ke hidupan bermasyarakat".(Barda NawawiArief, 2001:13

Masalah pelaksanaan /eksekusi pidana pembayaran uang pengganti pada dasarnya juga merupakan masalah penegakan hukum. Terkait dengan faktor-faktor yang menjadi kendala efektivitas pelaksanaan/eksekusi pidana pembayaran uang pengganti dalam tindak pidana korupsi di Pengadilan Negeri Poso. menurut Satjipto Rahardjo, ada dua fungsi yang dapat dimainkan oleh hukum yakni hukum sebagai social control, dan hukum sebagai social engineering. Selanjutnya Satjipto Rahar-djo mengatakan bahwa hukum sebagai kontrol sosial mengandung arti bahwa bertugas untuk menjaga masyarakat tetap berada di dalam pola-pola tingkah laku yang telah diterima olehnya.(Satjipto Rahardjo. 1980:117)

Dalam rangka perspektif hukum sebagai social control, fungsi utama sistem hukumbersifat integratif. Maksudnya hukum untuk mengatur dan memelihara regulitas sosial. Tanpa hukum, masyarakat bisa menjadi homohomini lupus (manusia yang satu menjadiserigala bagi manusia lainnya). Tiada masya-rakat yang bisa hidup lama tanpa kontrol sosial dari hukum sebagai sarananya.

Dalam fungsinya sebagai a tool of socialengineering memberikan dasar bagikemungkinan hukum dipergunakan untuk mengadakan perubahan masyarakat. Hukum dalam perspektif social engineering-lah yang paling banyak diper-gunakan oleh para pejabat untuk menggali sumber-sumber kekuasaan yang dapat dimobili-sasikan dengan menggunakan hukum sebagai mekanismenya. Upaya pengendalian sosial dengan menggunakan hukum sebagai sarananya itulah, oleh Roscou Pound disebut social engineering (rekayasa sosial). (Ronny Hanitijo Soemitro, 1985: 46)

Untuk menganalisis faktor-faktor yang menjadi kendala efektivitas pelaksanaan/eksekusi pidana pembayaran uang pengganti dalam tindak pidana korupsi di Pengadilan Negeri Poso terlebih dahulu perlu dikemukakan di sini pendapat dari Soerjono Soekanto. Dikemu-kakan oleh Soerjono Soekanto bahwa pada pokoknya masalah tersebut sebenarnya terletak pada faktor-faktor yang mungkin mempengaruhinya. Faktor-faktor tersebut mempunyai arti yang netral, sehingga dampak positif atau negatifnya terletak pada isi faktor-faktor tersebut. 
Pertama, faktor hukumnya sendiri, yang di dalam tulisan ini akan dibatasi pada peraturan perundang-undangan saja; kedua, faktor penegak hukum, yakni fihak-fihak yang membentuk maupun menerapkan hukum; ketiga, faktor sarana atau fasilitas yang mendukung penegakan hukum; keempat, faktor masyarakat, yakni ling-kungan di mana hukum tersebut berlaku atau diterapkan; dan kelima, faktor kebudayaan, yakni sebagai hasil karya, cipta dan rasa yang didasarkan pada karsa manusia di dalam per-gaulan hidup. Kelima faktor tersebut di atas saling berkaitan dengan eratnya, oleh karena merupakan esensi dari penegakan hukum, dan juga merupakan tolok ukur dari pada efektivitas penegakan hukum.

Soerjono Soekanto mengemukakan bahwa secara konsepsional, inti dan arti penegakan hukum terletak pada kegiatan menyelesaikan hubungan nilai-nilai yang terjabarkan di dalam kaidah-kaidah yang mantap dan mengejawantah dan sikap tindak sebagai rangkaian penjabaran nilai tahap akhir, untuk menciptakan, memeli-hara dan mempertahankan kedamaian pergaulan hidup. Konsepsi yang mempunyai dasar filo-sofis tersebut, memerlukan penjelasan lebih lanjut, sehingga akan tampak lebih konkrit.

Dalam penjelasan umum Undang-Undang No. 31 Tahun 1999 dinyatakan bahwa pembangunan nasional bertujuan mewujudkan manusia Indonesia seutuhnya dan masyarakat Indonesia seluruhnya yang adil, makmur, sejahtera, dan tertib berdasarkan Pancasila dan Undang-Undang Dasar 1945. Untuk mewujudkan masyarakat Indonesia yang adil, makmur, dan sejahtera tersebut, perlu secara terus-menerus ditingkatkan usaha-usaha pencegahan dan pem-berantasan tindak pidana pada umumnya serta tindak pidana korupsi pada khususnya.

Pertama, berdasarkan teori faktor yang pertama adalah faktor hukumnya sendiri, yang didalam tulisan ini akan dibatasi pada peraturan perundang-undangan saja. Dalam pelaksanaan/ eksekusi pidana pembayaran uang pengganti pada dasarnya juga merupakan masalah penegakan hukum. Hukum dapat mencerminkan nilai-nilai yang menjadi dasar dari hukum itu sendiri agar hukum atau peraturan perundang-undangan tersebut dapat berlaku efektif. Sehubungan dengan hal tersebut, peraturan perundang-undangan yang berkaitan dengan efektivitas pidana pembayaran uang pengganti dalam tindak pidana korupsi sesuai pasal 18 UU Tipikor, maka dari faktor hukumnya sendiri telah memiliki kelemahan dan kendala yang menghambat tujuan dari pengembaliann kerugian negara dari tindak pidana korupsi. Dalam kaitan pengembalian kerugian negara dalam tindak pidana korupsi penegak hukum paling terkait hal ini adalah penyidik dan Jaksa selaku pelaksana putusan pengadilan, penyidik sebagaimana ketentuan pasal 39 ayat 1 KUHAP bahwa "Benda atau tagihan tersangka atau terdakwa yang seluruh atau sebagai diduga diperoleh dari tindak pidana atau sebagian hasil dari tindak pidana" dari ayat tersebut dapat disimpulkan bahwa penyidik diberikan kewenangan menyita harta benda milik tersangka tindak pidana korupsi terbatas hanya pada harta benda yang diperoleh dari hasil tindak pidana korupsi. Dikaitkan dengan pasal 18 UU Tipikor bahwa perampasan harta benda milik tersangka adalah yang diperoleh dari tindak pidana korupsi yang dilakukan oleh tersangka. Kewengan penyidik terbatas dalam kewenangan yang dimiliki sesuai KUHAP dan UU Tipikor saja.

Dalam hal ini UU Tipikor dan hukum acara yang digunakan membatasi kewenangan penyidikan dengan hanya dapat melakukan penyitaan terhadap harta benda milik tersangka yang diperoleh atau patut diduga dari hasil tindak pidana korupsi yang dilakukan tersangka. Sehingga dari sisi faktor hukum ini turut mempengaruhi menjadi tidak efektiv dalam pengembalian keuangan negara dalam kasus-kasus tertentu salah satunya Putusan Nomor: 
28/Pid.Sus-TPK/2015/PN PAL dan Putusan pengadilan Negeri Poso Nomor: 12/Pid.Sus/ TPK/2014/PN. PAL. dalam penyidikannya perkara tindak pidana korpusi tersebut harta benda tersangka yang dapat disitaoleh penyidik jumlah atau nilai lebih kecil dibandingkan jumlah atau nilai kerugian negara yang terdapat pada tindak pidana korupsi yang dilakukan tersangka. Sehingga hal ini dapat menyulitkan pengembalian kerugian negara yang dilakukan oleh jaksa selaku pelaksana putusan pengadilan sebagaimana ketentuan pasal 18 UU Tipikor menyebutkan apabila terdakwa dalam satu bulan setelah putusan pengadilan berkekuatan hukum tetap, terdakwa tidak membayar uang pengganti maka jaksa dapat menyita dan melelang harta benda milik terdakwa untuk diperhitungkan sebagai pembayaran uang pengganti, apabila harta yang disita lebih kecil jumlah atau nilainya dari jumlah atau nilai kerugian negara yang timbul dalam tindak pidana korupsi yang dilakukan tersangka, sehingga Jaksa eksekutor harus mencari harta benda kekayaan terpidana untuk menutupi uang pengganti yang harus bayar terpidana, hal ini menjadi sulit karena kondisi ini dapat dijadikan celah oleh terpidana mengingat proses hukum tersebut membutuhkan waktu yang cukup bahkan bisa membutuhkan waktu yang lama, sehingga dalam kurun waktu proses hukum tersebut terpidana dapat mengalihkan, menyembunyikan atau menghilangkan harta kekayaanya sehingga harta yang harus disita dan dilelang Jaksatidak ditemukan lagi sehingga kerugian negara tidak dapat dikembalikan secara efektif.

Kedua, faktor penegak hukum, yakni pihak-pihak yang membentuk maupun menerapkan hukum. Pencapaian supremasi hukum harus diukur dari seberapa baik penegakan hukum yang dilakukan di Indonesia, berbicara mengenai penegakan hukum, maka hal paling penting dan mendasar adalah bagimana kemampuan aparat penegak hukum (khususnya dalam bidang tindak pidana korupsi), dalam sistem peradilan dapat mengakomodasi dan mengapresiasi tuntutan keadilan baik yang menjadi ruh hukum formal maupun tuntutan rasa keadilan oleh masyarakat dalam pemberantasan korupsi merupakan suatu kebutuhan dasar.

Dikemukakan oleh Soerjono Soekanto, sebagai salah satu faktor yang menentukan proses penegakan hukum adalah tidak hanya pihak-pihak yang menerapkan hukum tetapi juga pihak-pihak yang membuat hukum. Dalam pem-bahasan ini dibicarakan mengenai pihak-pihak yang terkait langsung dengan penerapan hu-kum. Pihak-pihak dalam proses penegakan hu-kum dimaksud yaitu kepolisian, kejaksaan, kehakiman dan kepengacaraan.

Keterbatasan penyidik dalam mengungkapkan atau mendata harta kekayaan tersangka dalam tindak pidana korupsi sehingga dapat dimanfaatkan tersangka untuk menyimbunyikan, mengalihkan atau memindahtangankan harta bendanya kepada yang lain. Dalam ini kewenangan penyidik menyita harta benda tersangka yang diketahui atau patut diduga dari hasil tindak pidana korupsi.

Jaksa selaku eksekutor untuk mencari cara bagaimana melakukan putusan. Dalam kaitannya dengan perkara ini Jaksa merasa sulit untuk melacak harta benda milik terpidana yang diperoleh dari hasil tindak pidana korupsi. Setelah dilakukan pencarian harta benda oleh Jaksa Penuntut Umum tidak ditemukan adanya harta benda milik terdakwa untuk membayar uang pengganti.

Ketiga, faktor fasilitas, dalam hal pengembalian uang pengganti dalam tindak pidana korupsi. Faktor fasilitas juga salah satu yang menjadi kendala. Dalam hal ini minimnya dana yang diberikan negara. Apabila jumlah atau nilai harta benda yang disita lebih kecil 
dibandingkan jumlah atau nilai kerugian kerugian negara yang terdapat dalam tindak pidana korupsi maka jaksa harus mencari kembali harta milik terpidana untuk disita dan dilelang utuk menutupi selisih uang pengganti yang harus dibayar oleh terpidana. Namun pencarian ini tidak imbangi dan didukung fasilitas yang memadai guna berhasilnya pencarian harta atau penulusuran aset milik terdakwa untuk menutupi kekurangan kerugian negara.

Keempat, faktor masyarakat, yakni lingkungan di mana hukum tersebut berlaku atau diterapkan. Bagian terpenting dari masyarakat dalam yang menentukan penegakan hukum adalah kesadaran hukum masyarakat. Peraturan hukum yang berlaku atau diterapkan mempunyai pengaruh yang kuat terhadap pelaksanaan pene-gakan hukum. Sebab penegakan hukum berasal dari masyarakat dan bertujuan untuk mencapai kedamaian dan keadilan dalam masyarakat.

Kaitannya dengan faktor yang menjadi kendala efektivitas pelaksanaan/eksekusi pidana pembayaran uang pengganti dalam tindak pidana korupsi di poso adalah kurangnya kesadaran dari masyarakat untuk melaporkan atau memberitahukan tindak pidana korupsi di lingkungannya serta harta benda yang dimiliki terdakwa, kepedulian atau kesadaran masyarakat untuk memberikan infor-masi secara dini kepada penegak hukum ter-hadap orang yang dicurigai melakukan tindak pidana korupsi masih kurang, justru ada kecen-derungan untuk turut menutup-nutupi.

Sehubungan dengan faktor masyarakat yang ikut mempengaruhi penegakan hukum ini, apabila dikaitkan dengan pendapat Friedman tentang unsur-unsur dalam sistem hukum yang salah satu unsurnya adalah "budaya hukum" yaitu sikap-sikap dan nilai yang berhubungan dengan hukum, yang datangnya dari rakyat atau pemakai jasa hukum. ${ }^{1}$ maka dapat di kemukakan bahwa budaya hukum masyarakat yang dicerminkan antara lain dengan sikap masyarakat yang enggan memberikan informasi ten-tang adanya pelaku tindak pidana korupsi atau harta benda yang dimiliki oleh pelaku kejabatan di lingkungannya, menunjukan adanya budaya hukum masyarakat yang belum mendukung penegakan tindak pidana korupsi. Sehingga dapat dikatakan bahwa faktor masyarakat khususnya budaya hukum masyarakat merupakan faktor penghambat dalam penanggulangan tindak pidana korupsi. Kemudian masyarakat juga bersedia melakukan transaksi tanpa mencari tahu seseorang lawan transaksi tersebut masih dalam proses hukum dalam hal ini tindak pidana korupsi.

Putusan penjatuhan pidana tambahan uang pengganti dalam putusan perkara korupsi di Pengadilan Negeri Poso Putusan Nomor: 28/Pid.Sus-TPK/2015/PN PAL dan Putusan pengadilan Negeri Poso Nomor: 12/Pid.Sus/TPK/2014/PN. PAL. uang pengganti yang seharusnya dikembalikan oleh terpidana kepada negara tidak seluruhnya mengembalikan, terdakwa ada yang tidak membayar uang pengganti sebagaimana terdapat dalam Putusan Nomor: 28/Pid.Sus-TPK/2015/PN PAL dan Putusan pengadilan Negeri Poso Nomor: 12/ Pid.Sus/TPK/2014/PN. PAL pembayaran uang pengganti belum terbayarkan dikarenakan terdakwa tidak mau membayar, Putusan Nomor: 28/Pid.Sus-TPK/2015/PN PAL dan Putusan pengadilan Negeri Poso Nomor: 12/Pid.Sus/TPK/2014/PN. PAL. setelah dilakukan pencarian harta benda oleh JPU tidak ditemukan adanya harta benda untuk membayar uang pengganti. Sesuai pasal 18 UU Tipikor apabila terpidana satu bulan setelah putusan berkekuatan tetap terpidana tidak membayar uang pengganti maka harta bendanya dapat disita dan dilelang oleh Jaksa untuk diperhitungkan sebagai uang pembayaran uang pengganti, apabila terpidana

1 Abdul Manan, 2005, Aspek-aspek Pengubah Hukum, Yakarta: Prenada Media Group,. hlm. 9 
tidak memiliki harta benda yang mencukupi untuk diperhitungkan sebagai uang pengganti maka terpidana dipidana dengan pidana penjara subsider sebagaimana terdapat dalam putusan tersebut 2 bulan pidana penjara.

Hambatan dari faktor masyarakat, kurangnya kesadaran dari masyarakat untuk melaporkan atau memberitahukan tindak pidana korupsi di lingkungannya, kepedulian atau kesadaran masyarakat untuk memberikan informasi secara dini kepada penegak hukum terhadap orang yang dicurigai melakukan tindak pidana korupsi masih kurang. Terdakwa yang seharusnya mengembalikan uang pengganti namun tidak bisa membayar uang pengganti.

\section{Simpulan}

Berdasarkan teori faktor yang pertama adalah faktor hukumnya sendiri, yang didalam tulisan ini akan dibatasi pada peraturan perundang-undangan saja. Dalam pelaksanaan/ eksekusi pidana pembayaran uang pengganti pada dasarnya juga merupakan masalah penegakan hukum. Dalam hal ini UU Tipikor dan hukum acara yang digunakan membatasi dalam hal kewenangan penyidikan membatasi penyidik hanya dapat melakukan penyitaan terhadap harta benda milik tersangka yang diperoleh atau patut diduga dari hasil tindak pidana korupsi yang dilakukan tersangka. Kedua, faktor penegak hukum, yakni pihak-pihak yang membentuk maupun menerapkan hukum.Keterbatasan penyidik dalam mengungkapkan atau mendata harta kekayaan tersangka dalam tindak pidana korupsi sehingga dapat dimanfaatkan tersangka untuk menyimbunyikan, mengalihkan atau memindahtangankan harta bendanya kepada yang lain. Dalam ini kewenangan penyidik menyita harta benda tersangka yang diketahui atau patut diduga dari hasil tindak pidana korupsi. Ketiga, faktor fasilitas, dalam hal pengembalian uang pengganti dalam tindak pidana korupsi. Faktor fasilitas juga salah satu yang menjadi kendala. Dalam hal ini minimnya dana yang diberikan negara. Apabila jumlah atau nilai harta benda yang disita lebih kecil dibandingkan jumlah atau nilai kerugian kerugian negara yang terdapat dalam tindak pidana korupsi maka jaksa harus mencari kembali harta milik terpidana untuk disita dan dilelang utuk menutupi selisih uang pengganti yang harus dibayar oleh terpidana. Keempat, faktor masyarakat, yakni lingkungan di mana hukum tersebut berlaku atau diterapkan adalah kurangnya kesadaran dari masyarakat untuk melaporkan atau memberitahukan tindak pidana korupsi di lingkungannya serta harta benda yang dimiliki terdakwa,

\section{E. Saran}

Dalam hal mencermati proses pengembalian uang pengganti dalam tindak pidana korupsi sudah seyognya kita melakukan sebuah pembaharuan hukum terkait kewenangan penyidik dalam hukum acara pidana maupu UU Tipikor itu sendiri, meningkatkan kemampuan penegak hukum dalam hal ini penyidik dan jaksa eksokutor yang didukung dengan sarana prasarana yang memadai, serta perlunya kesadaran masyarakat dalam mendukung upayaupaya penegakan hukum sehingga atas perubahan terutama perluasan kewenangan penyidik dapat berdampak pada efektivnya pengembalian kerugian negara. 


\section{F. Daftar Pustaka}

\section{Buku}

Abdul Manan. 2005. Aspek-aspek Pengubah Hukum.Jakarta: Prenada Media Group.

Barda Nawawi Arief. 2001. Masalah Penegakan Hukum dan Kebijakan Penanggulangan Kejahatan, Bandung: Citra Aditya Bakti.

Basrief Arief. 2014. Pemulihan Aset Hasil Kejahatan dalam Pemberantasan Tindak Pidana Korupsi. Workshop Pemulihan Aset Tindak Pidana, Mahupiki. Jakarta, 28-29 Agustus.

Evi Hartanti. 2007. Tindak Pidana Korupsi dan Penegakan Hukum. Jakarta, Sinar Grafika.

Romli Atmasasmita. 2004. sekitar Masalah Korupsi Aspek Nasional dan Aspek Internasional. Bandung. Mandar Maju.

Pedoman Pembimbingan tesis dan Pedoman Penulisan Usulan penelitian dan Tesis, Sebelas Maret Sarakarta. 2015.

Satjipto Rahardjo. 1980. Hukum dan Masyarakat. Bandung: Angkasa.

Ronny Hanitijo Soemitro. 1985. Studi Hukum dan Masyarakat. Bandung: Alumni.

\section{Jurnal}

Abd Razak Musahib. 2015. Pengembalian Keuangan Negara Hasil Tindak Pidana Korupsi. e-Jurnal Katalogis. Volume 3 Nomor 1, Januari.

Ade Paul Lukas. 2010. Efektivitas Pidana Pembayaran Uang Pengganti dalamTindak Pidana Korupsi (Studi Putusan Tindak Pidana Korupsi Di Pengadilan Negeri Purwokerto), Jurnal Dinamika Hukum. Vol. 10 No. 2 Mei.

Muhammad Nurul Huda, 2016. Model Perampasan Asset Transaksi Keuangan yang mencurigakan dari Hasil kejahatan Pencucian Uang, Disertasi. Universitas Sebelas Maret. 